\title{
PATTERN OF CHEST INJURIES IN FATAL ROAD TRAFFIC ACCIDENTS- AN AUTOPSY STUDY
}

\author{
Ravi Kumar K1, Rajeev V. $M^{2}$
}

1 Junior Resident, Department of Forensic Medicine, Government Medical College, Kottayam, Kerala, India. ${ }^{2}$ Associate Professor, Department of Forensic Medicine, Government Medical College, Kottayam, Kerala, India.

\section{BACKGROUND} ABSTRACT

India is a signatory to the Brasilia declaration and is committed to reduce the number of road accidents and fatalities by $50 \%$ by 2020. However, with one of the highest motorisation growths in the world accompanied by rapid expansion in road networks and urbanisation over the years, our country is faced with serious impacts on road safety levels. Trauma to the chest is the second most common injury found in road traffic accidents. Chest injuries accounts for $25 \%$ of deaths in trauma victims. It is second only to traumatic brain injury in mortality.

The aim of this study is to analyse the pattern of chest injuries in fatal road traffic accidents.

\section{MATERIALS AND METHODS}

An autopsy-based descriptive analysis was conducted.

Sample Size- A total of 161 cases of fatal road traffic accidents with chest injuries was studied during the period of 12 months from 04.02.2016 to 03.02.2017.

Source Population- All cases of fatal road traffic accidents with chest injuries brought for post mortem examination to the Department of Forensic Medicine, Govt. Medical College, Kottayam during the study period was included in the study.

Inclusion Criteria- All autopsies in which death was due to chest injuries in road traffic accidents were included in the study.

Exclusion Criteria- All unidentified bodies and cases in which proper history was not available.

Data Collection- Baseline data like age, sex, height, weight and a brief history of the case were collected from the relatives and investigating officers. A detailed information regarding the nature, time of accident, type of vehicle involved, and category of victim were recorded from the investigating officer and hospital records in case of treated cases. Details of external injuries and chest injuries are recorded in the proforma.

Analysis- Data collected was entered in MS-Excel and analysed using IBM SPSS Version 16.

\section{RESULTS}

Among the 161 cases of fatal road traffic accident victims with chest injuries, 136 (84.5\%) were males and 25 (15.5\%) were females. Maximum number of victims, 57 (35.4\%) were in the age group of 45 - 60 years. Maximum number of accidents, 34 (21.1\%) occurred in the month of August and least occurred in the month of October (3.1\%). Maximum number of accidents (41.6\%) occurred during the time $12 \mathrm{PM}$ to $6 \mathrm{PM}$ and least occurrence (4.3\%) was between $12 \mathrm{AM}$ to 6 AM. Two wheelers were the commonest vehicles involved (53.4\%) followed by car (31.7\%). In case of collisions, cars colliding with two wheelers was the commonest (14.3\%) followed by two wheelers colliding with heavy vehicles (13\%). Majority of victims involved were pedestrians (38.5\%) followed by motor cyclists (35.4\%). Among the motor cyclists, those wearing helmets were 17 (10.6\%) and those occupants with seat belts were only $2(1.2 \%)$. Among the driver, $22(13.7 \%)$ were under the influence of alcohol and among the other victims $29.2 \%$ have consumed alcohol. Among the fatal cases $10.6 \%$ died on the spot, 38.5\% died within 6 hours and $41.6 \%$ died within 24 hours. Sternum was fractured in 34.2\%, bilateral rib fractures seen in 54.6\% and unilateral fracture in $45.4 \%$. Regarding fracture of thoracic vertebrae, the $4^{\text {th }}$ thoracic vertebra was fractured in $11(6.8 \%)$ followed by fracture of 1 st and $12^{\text {th }}$ thoracic vertebrae in 4 (2.5\%) cases each. Both clavicles were fractured in 6 (3.7\%). Right lung showed contusion in 58.4\%, while left lung was involved in $65.9 \%$. Laceration of right lung was seen in $40.4 \%$, while left lung was involved in $37.9 \%$. Laceration of aorta was seen in $26(16.1 \%)$ cases. Contusion of heart was seen in 34 (21.1\%) cases. Laceration of heart was seen in 6 (3.7\%) cases. Associated injury to head was seen in 121 (75.2\%) cases. Of which $25.5 \%$ had intracranial haemorrhages and $49.7 \%$ had fracture of skull. Fracture of cervical spine was seen in 19 (11.8\%) cases, while $44.7 \%$ showed fracture of any of the limbs. Laceration of liver was seen in 54 (33.5\%) and spleen was lacerated in $11(6.8 \%)$ of cases.

\section{CONCLUSION}

The mechanism and circumstances of blunt chest injury due to road traffic accidents can be assessed in relation to the number and localisation of rib fractures as well as the presence of injuries to lung, heart and major blood vessels. The most common cause of death 82 (50.9\%) was combined injuries to head and chest followed by injuries to head, chest and abdomen 38 (23.6\%) and only $6.8 \%$ of cases died due to chest injuries alone.

\section{KEY WORDS}

Road Traffic Accidents, Chest Injury, Pedestrians, Occupants, Motor Cyclists.

HOW TO CITE THIS ARTICLE: Kumar RK, Rajeev VM. Pattern of chest injuries in fatal road traffic accidents- an autopsy study. J. Evolution Med. Dent. Sci. 2018;7(44):4758-4764, DOI: 10.14260/jemds/2018/1062 
'Financial or Other Competing Interest': None.

Submission 11-09-2018, Peer Review 10-10-2018,

Acceptance 17-10-2018, Published 29-10-2018.

Corresponding Author:

Dr. Rajeev V. M,

Associate Professor,

Department of Forensic Medicine,

Kottayam-686008, Kerala.

E-mail: drrajeevvm3056@gmail.com

DOI: $10.14260 /$ jemds $/ 2018 / 1062$

\section{(c) $(1)$}

\section{BACKGROUND}

Road traffic accidents are a human tragedy. They involve high human sufferings and socio-economic loss in terms of premature deaths, injuries and loss of productivity. ${ }^{1}$ Nearly, 1.3 million people die every year in the world due to road traffic accidents and 20 - 50 million people suffer non-fatal injuries leading to disability. ${ }^{2}$ Road traffic accidents are the leading cause of death in young people aged 15 - 29 years and costs countries $1-3 \%$ of the country's GDP. ${ }^{3}$ According to WHO, road traffic accidents are the sixth leading cause of death in India with a greater share of economic losses in the young and middle-aged population. ${ }^{4}$ Seat belt injuries: in severe collisions if the person is wearing seat belt, injuries on the chest and abdomen may be caused. Compression on the chest wall will lead to contusions and injuries to mediastinal structures. These injuries are collectively known as 'seat belt' syndrome. ${ }^{5}$ Falling from motor cycles in high speed produce injuries to extremities as well as chest and abdomen. ${ }^{6}$ Mobile phones have become one of the serious threats leading to road traffic accidents. Studies have shown that 'Reaction Time' of drivers has increased when they are using mobile phones while driving from $0.5 \mathrm{sec}$ to 1.5 secs. ${ }^{7}$ The Relative Risks (RR) for injury collisions and also for all collisions is $38 \%$ higher for men and women cell phone users. These risks diminish to 1.1 for men and 1.2 for women, if other variables such as the kilometres driven and driving habits are incorporated into the models. ${ }^{8}$ A study on traffic injury prevention by Johnson $\mathrm{MB}$ and others found that mobile phone usage was decreased towards weekends, when exceeding their speed limits and when other passengers are travelling along with them. ${ }^{9}$ Hands free mobile phones or hands free speaker phones possess a significantly lower risk rate than who have hand-held phones. ${ }^{10}$

\section{Objectives}

1. To study the pattern of chest injuries in fatal road traffic accidents.

2. To analyse the survival period and cause of death in fatal road traffic accidents.

\section{MATERIALS AND METHODS}

An autopsy-based descriptive analysis was conducted.

\section{Sample Size}

A total of 161 cases of fatal road traffic accidents with chest injuries was studied during the period of 12 months from 04.02.2016 to 03.02.2017.

\section{Source Population}

All cases of fatal road traffic accidents with chest injuries brought for post mortem examination to the Department of Forensic Medicine, Govt. Medical College, Kottayam during the study period was included in the study.

\section{Inclusion Criteria}

All autopsies in which death was due to chest injuries in road traffic accidents were included in the study.

\section{Exclusion Criteria}

All unidentified bodies and cases in which proper history was not available.

Data collection: Baseline data like age, sex, height, weight and a brief history of the case were collected from the relatives and investigating officers. A detailed information regarding the nature, time of accident, type of vehicle involved, and category of victim were recorded from the investigating officer and hospital records in case of treated cases. Details of external injuries and chest injuries are recorded in the proforma.

\section{Analysis}

Data collected was entered in MS-Excel and analysed using IBM SPSS version 16.

\section{RESULTS}

The study was conducted in the Department of Forensic Medicine, Govt. Medical College, Kottayam during the period from 04.02.2016 to 03.02.2017. A total number of 161 fatal cases in Road Traffic Accidents with chest injuries were analysed on the basis of history and post-mortem findings.

\section{Epidemiology of Fatal Road Traffic Accidents: Gender Wise Distribution}

Out of the 161 cases in the present study, majority of the victims were males, 136 cases $(84.5 \%)$ and 25 cases $(15.5 \%)$ were females.

\section{Age Distribution}

Maximum number of victims (57 cases) belonged to age group of $45-60$ years followed by age group of $60-70$ years (35 cases). The following table depicts age group distribution and the corresponding gender distribution.

\begin{tabular}{|c|c|c|c|c|c|c|}
\hline \multirow{3}{*}{\begin{tabular}{|c|}
$\begin{array}{c}\text { Age } \\
\text { Group in } \\
\text { Years }\end{array}$ \\
$15-30$ \\
\end{tabular}} & \multicolumn{4}{|c|}{ Gender } & \multirow{3}{*}{$\begin{array}{c}\text { Total } \\
26\end{array}$} & \multirow{3}{*}{\begin{tabular}{|c} 
Percentage \\
(N=161)
\end{tabular}} \\
\hline & \multicolumn{2}{|c|}{$\begin{array}{c}\text { Male } \\
(\mathrm{N}=136)\end{array}$} & \multicolumn{2}{|c|}{ Female $(\mathrm{N}=25)$} & & \\
\hline & 25 & $18.4 \%$ & 01 & $04 \%$ & & \\
\hline $30-45$ & 23 & $16.9 \%$ & 01 & $04 \%$ & 24 & 14.3 \\
\hline $45-60$ & 47 & $34.6 \%$ & 10 & $40 \%$ & 57 & 35.4 \\
\hline $60-75$ & 27 & $19.8 \%$ & 08 & $32 \%$ & 35 & 21.7 \\
\hline $75-90$ & 14 & $10.3 \%$ & 05 & $20 \%$ & 19 & 11.8 \\
\hline Total & & 36 & & 5 & 161 & \\
\hline
\end{tabular}




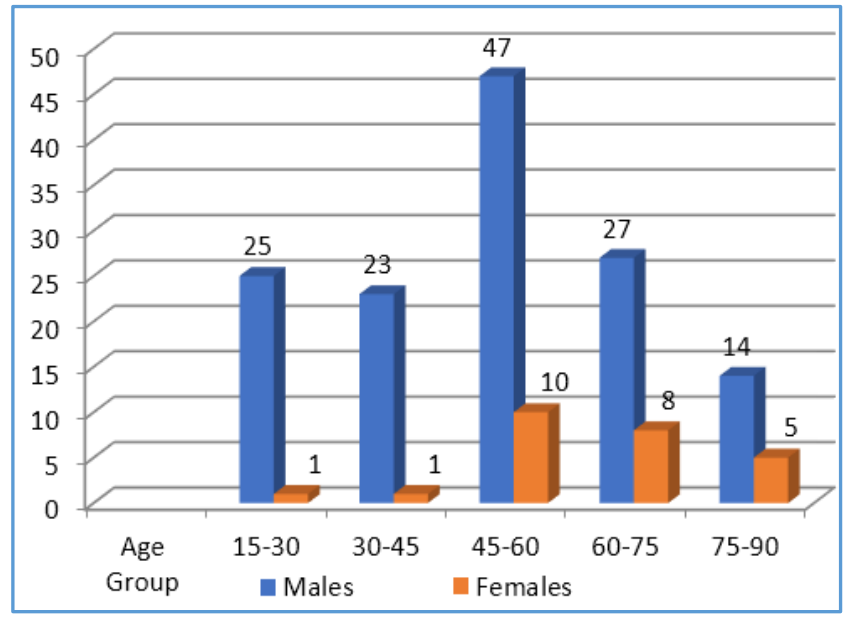

Figure 1. Distribution of Victims based on their Age Group and Gender

\section{Time of Occurrence}

In the present study, it was observed that maximum number of accidents were seen between 12 PM and 6 PM (41.6\%) followed by $6 \mathrm{PM}$ and $12 \mathrm{AM}(28 \%)$ and least occurrence was between $12 \mathrm{AM}$ and $6 \mathrm{AM}(4.3 \%)$.

\begin{tabular}{|c|c|}
\hline Time & Distribution of Cases (\%) \\
\hline 12 AM - 6 AM & 04.3 \\
\hline $6 \mathrm{AM}-12 \mathrm{PM}$ & 26.1 \\
\hline 12 PM - 6 PM & 41.6 \\
\hline 6 PM - 12 AM & 28.0 \\
\hline Table 2. Distribution of Cases based on Time of Occurrence \\
\hline
\end{tabular}

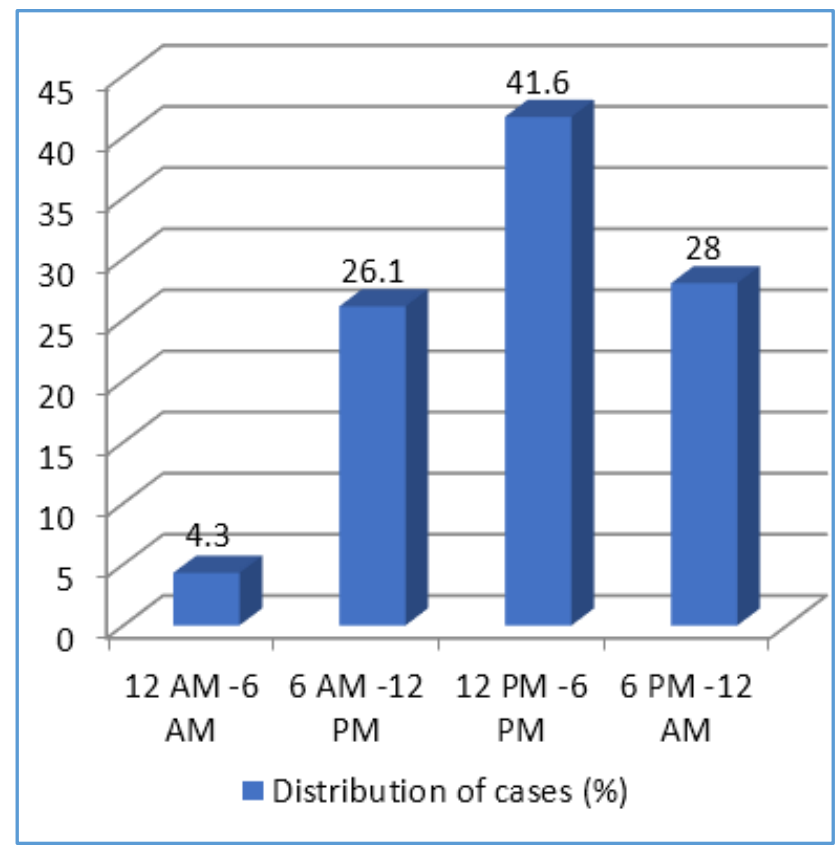

Figure 2. Distribution of Cases based on the Time of Occurrence

\section{Month of Occurrence}

Of the total number of cases, maximum cases occurred during the month of August and least occurred during the month of October

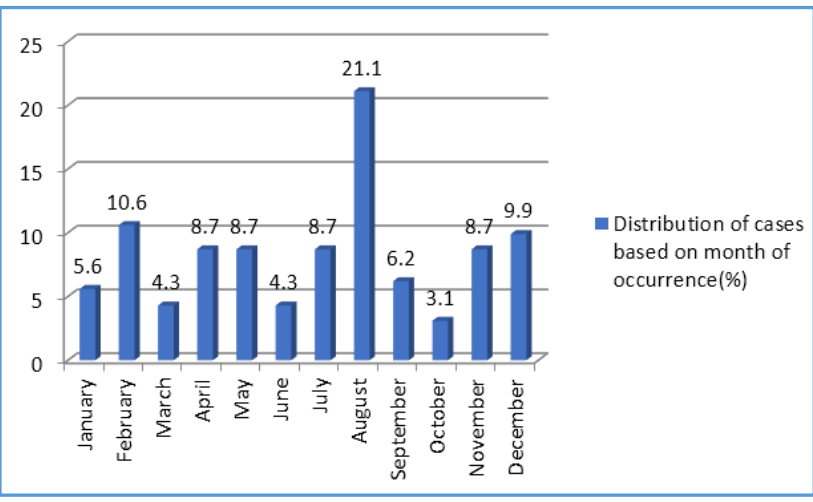

Figure 3. Distribution of Cases based on Month of Occurrence (\%)

\section{Type of Vehicles Involved}

Out of the 161 cases studied 86 cases were two wheelers, 51 cases were light motor vehicles and the remainder were heavy motor vehicles.

\begin{tabular}{|c|c|c|}
\hline Types of Vehicles & No. of Cases & Percentage \\
\hline Two Wheelers & 86 & 53.4 \\
\hline LMV & 51 & 31.7 \\
\hline HMV & 24 & 14.9 \\
\hline Total & $\mathbf{1 6 1}$ & $\mathbf{1 0 0 . 0}$ \\
\hline \multicolumn{2}{|c|}{ Table 3. Distribution of Vehicles Involved } \\
\hline
\end{tabular}

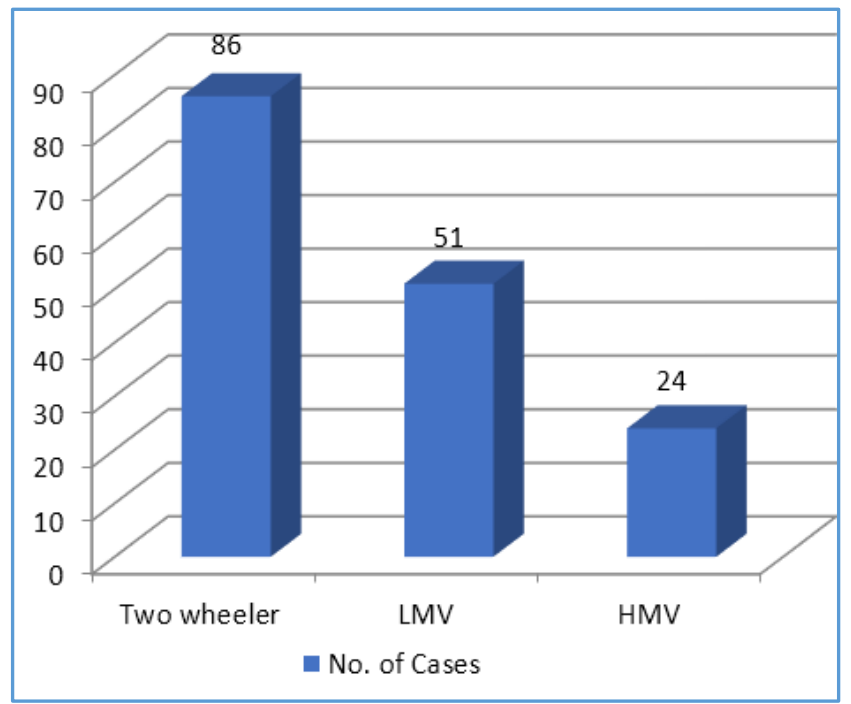

Figure 4. Distribution of Type of Vehicles Involved

Type of Victims Involved

Most of the victims involved were pedestrians (62 cases) followed by riders of motor cycles (57 cases). Others were drivers 18, pillion rider (15), side seaters (3) and back seaters (6).

\begin{tabular}{|c|c|c|}
\hline Type of Victims & No. of Cases & Percentage \\
\hline Pedestrian & 62 & 38.5 \\
\hline Driver & 18 & 11.2 \\
\hline Motor cyclists & 57 & 35.4 \\
\hline Pillion rider & 15 & 9.3 \\
\hline Side seaters & 3 & 1.9 \\
\hline Back seaters & 6 & 3.7 \\
\hline Total & $\mathbf{1 6 1}$ & $\mathbf{1 0 0 . 0}$ \\
\hline \multicolumn{2}{|c}{ Table 4. Types of Victims Involved } \\
\hline
\end{tabular}




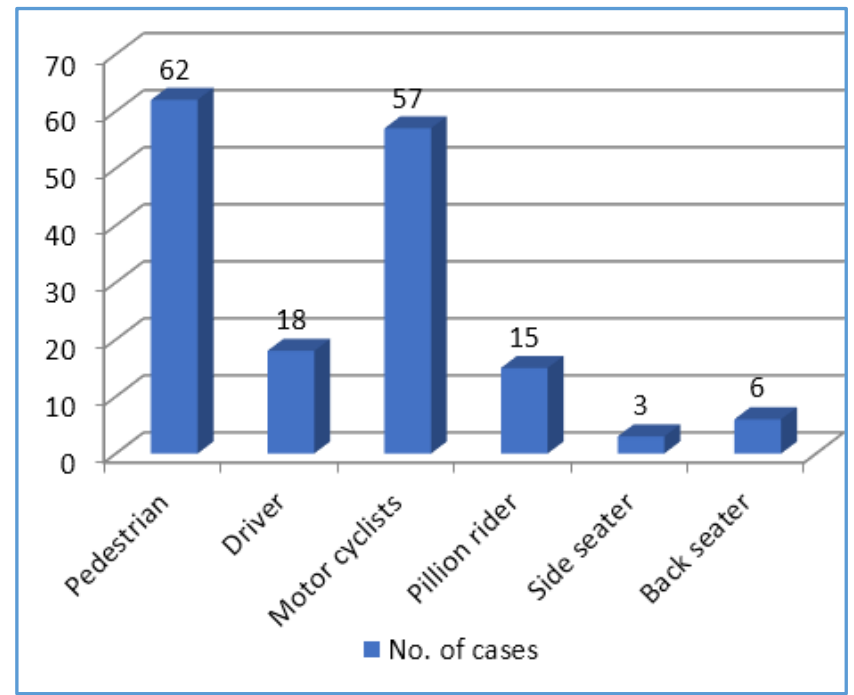

Figure 5. Types of Victims Involved

Distribution of Safety Precautions Adopted by the Victims

Of the 161 cases, 83 persons did not have any safety precautions. 17 cases wore helmets and only 3 cases wore seat belts.

\section{Alcohol Consumption}

Out of 161 cases, 69 have consumed alcohol. Among these, 22 cases were either drivers or riders and 47 were pedestrians or occupants of vehicles.

\section{Period of Survival}

Of the 161 cases 17 (10.2\%) have died on the spot, 62 cases $(38.5 \%)$ survived for less than 6 hours, while 67 cases (41.6\%) survived more than 24 hours and were hospitalised.

\begin{tabular}{|c|c|c|}
\hline Period of Survival & No. of Cases & Percentage \\
\hline Died on the spot & 17 & 10.2 \\
\hline Less than 6 hours & 62 & 38.5 \\
\hline More than 24 hours & 67 & 41.6 \\
\hline \multicolumn{2}{|c|}{ Table 5. Table showing Period of Survival } \\
\hline
\end{tabular}

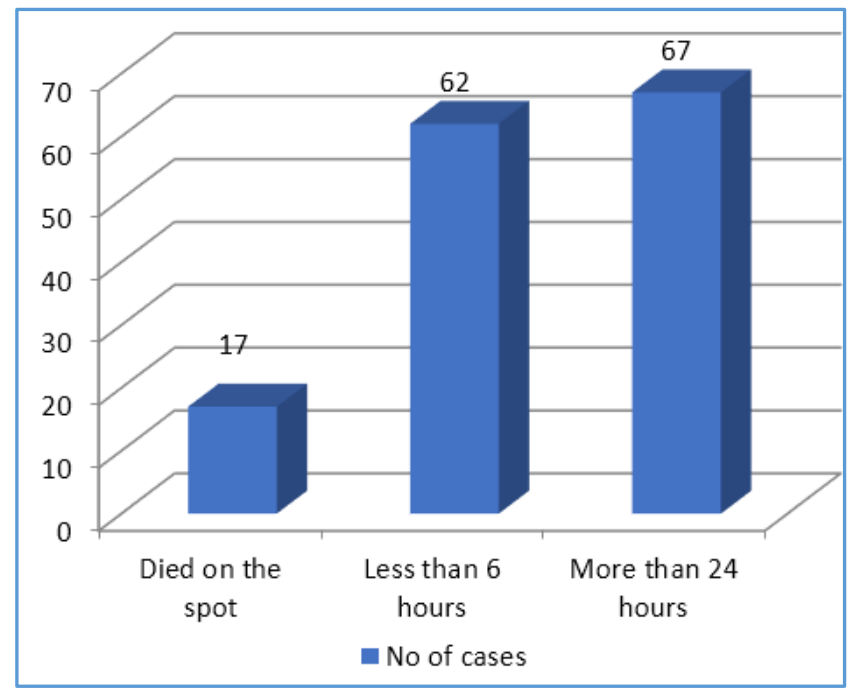

Figure 6. Period of Survival of Victims

\section{Pattern of Chest Injuries}

Fracture of sternum was present in 55 (34.2\%) cases, while $106(65.8 \%)$ cases of victims did not have fracture of sternum. Fracture of sternum seen in direct impact is the major cause for haemothorax and injuries to pericardium and heart.

Distribution of Fracture Sternum in different Categories of Victims

Of the 62 pedestrians who succumbed to death, 25 persons $(21.8 \%)$ had fracture of sternum. Side seat occupants had only $1.8 \%$ of sternum fracture. The most common site of fracture sternum was between $1^{\text {st }}$ and $2^{\text {nd }}$ costal cartilages followed by $2^{\text {nd }}$ and $3^{\text {rd }}$ costal cartilages.

\begin{tabular}{|c|c|c|c|}
\hline $\begin{array}{l}\text { Type of } \\
\text { Victim }\end{array}$ & $\begin{array}{c}\text { Fracture of } \\
\text { Sternum }\end{array}$ & $\begin{array}{l}\text { No. Fracture of } \\
\text { Sternum }\end{array}$ & Total \\
\hline Pedestrian & 25 & 37 & 62 \\
\hline Driver & 10 & 8 & 18 \\
\hline Motorcyclist & 12 & 45 & 57 \\
\hline Pillion rider & 5 & 10 & 15 \\
\hline Side seat & 1 & 2 & 3 \\
\hline Back seat & 2 & 4 & 6 \\
\hline Total & 55 & 106 & 161 \\
\hline \multicolumn{4}{|c|}{$\begin{array}{c}\text { Table 6. Distribution of Study Sample showing Fracture of } \\
\text { Sternum among Different Categories of Victims }\end{array}$} \\
\hline
\end{tabular}

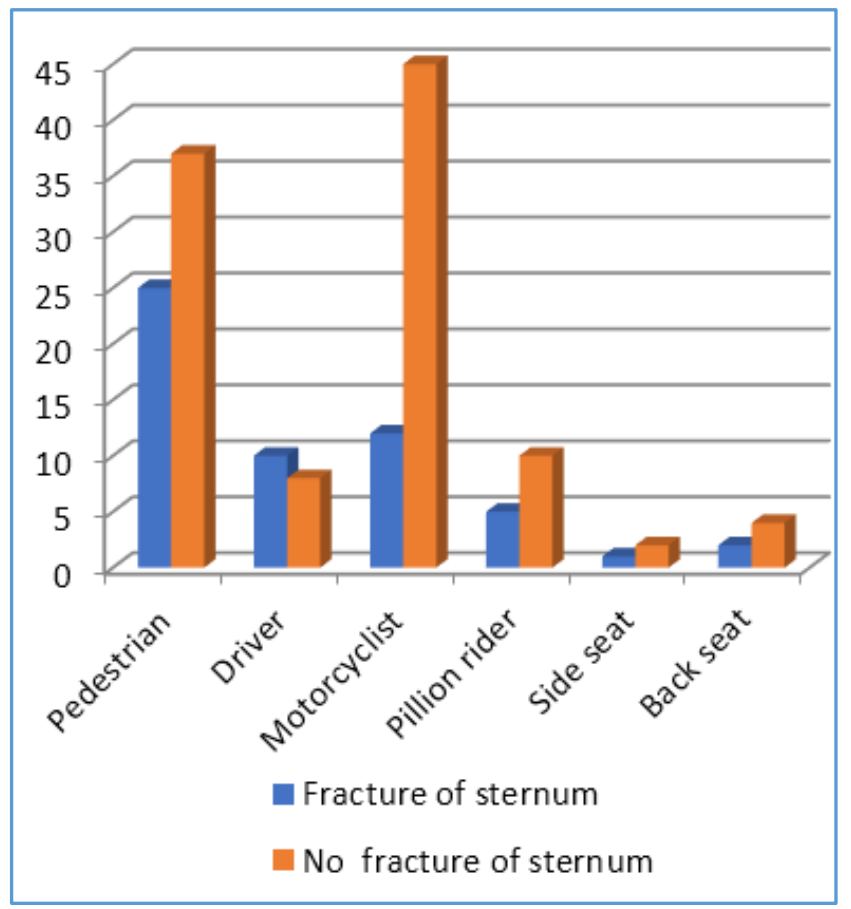

Figure 7. Distribution of Study Sample showing Fracture of Sternum among Different Categories of Victims

\section{Fracture of Ribs}

A rib fracture secondary to blunt thoracic trauma is an important indicator of the trauma. Of the 161 cases studied 88 (54.6\%) cases had bilateral rib fractures and 73 (45.4\%) cases showed unilateral rib fracture. Out of 161 cases, 149 had haemothorax and 12 cases had no haemothorax. 


\section{Fracture of Sternum}

Fracture of sternum in direct impact is one of the causes of haemothorax and injuries to heart and pericardium. In the present study, sternum was fractured in 55 cases (34.2\%).

\begin{tabular}{|c|c|c|}
\hline Type of Victim & \# Sternum Present & \# Sternum Absent \\
\hline Pedestrian & 25 & 37 \\
\hline Driver & 10 & 8 \\
\hline Motor Cyclist & 12 & 45 \\
\hline Pillion Rider & 5 & 10 \\
\hline Side Seat & 1 & 2 \\
\hline Back Seat & 2 & 4 \\
\hline Total & 55 & 106 \\
\hline \multicolumn{3}{|c|}{$\begin{array}{l}\text { Table 7. Distribution of Fracture Sternum in } \\
\text { different types of Victims }\end{array}$} \\
\hline
\end{tabular}

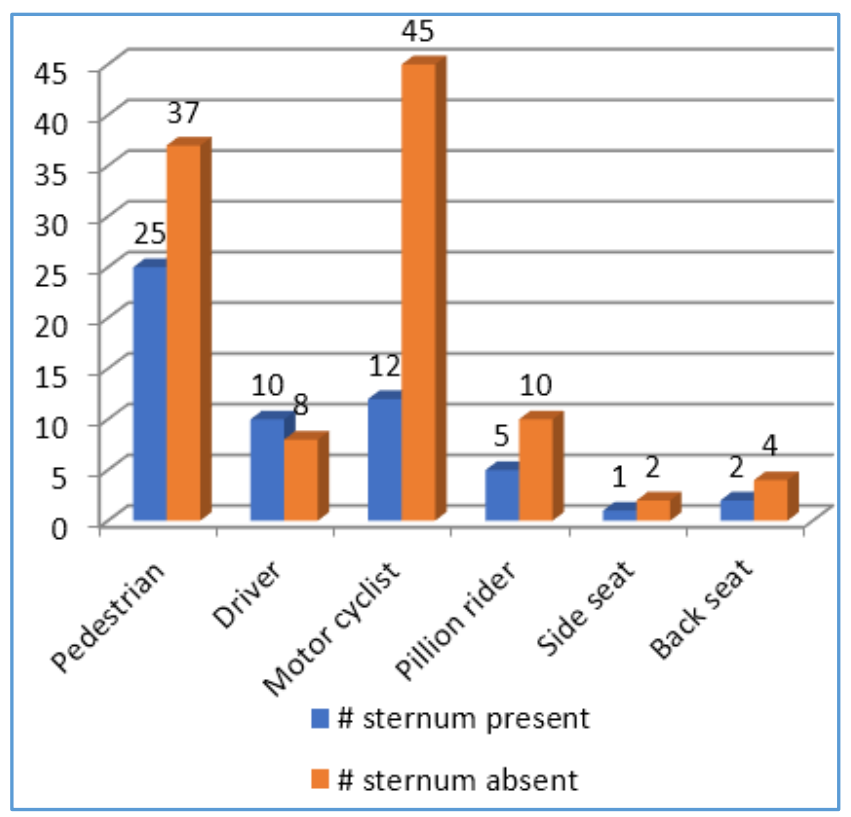

Figure 8. Distribution of Fracture Sternum in different types of Victims

Fracture of Thoracic Vertebra

Older individuals were found to be almost 5 times more likely to sustain spinal injury compared to younger individuals. Among the 161 cases, 33 cases had fracture of spinal column and 19 cases had fracture of thoracic vertebrae.

\section{Fracture of Clavicle}

Among the 161 cases, $78(48.4 \%)$ cases had fracture of clavicle and in 6 cases there was bilateral clavicle fracture.

\section{Fracture of Scapula}

It is relatively uncommon. In the present study there were 5 cases (3.1\%) of scapular fracture, of which 3 were bilateral.

\section{Lung Injury}

Contusion of lung was the most common injury found in blunt trauma to chest. It is usually caused by deceleration that results when the moving chest strikes a fixed object like the steering wheel. Right lung was contused in 62 cases (38.5\%). Left lung was contused in 38 cases $(23.6 \%)$.

\section{Cardiac Contusions}

Among the 161 cases, 34 (21.1\%) cases showed evidence of cardiac contusion. The favoured sites of cardiac contusions were right ventricle 18 cases (52.9\%) and right atrium 16 (47.1\%) cases.

\section{Injuries to Aorta}

Among the 161 cases in the present study, aorta was injured in $26(16.1 \%)$ cases, of which $16(9.9 \%)$ cases showed involvement of ascending aorta, in $4(2.5 \%)$ cases descending aorta was involved and in $6(3.7 \%)$ cases the arch of aorta was involved.

\begin{tabular}{|c|c|c|}
\hline Region of Aorta & No. of Cases & Percentage \\
\hline Ascending aorta & 16 & 61.5 \\
\hline Descending aorta & 4 & 15.4 \\
\hline Arch of aorta & 6 & 23.1 \\
\hline Total & 26 & 100 \\
\hline
\end{tabular}

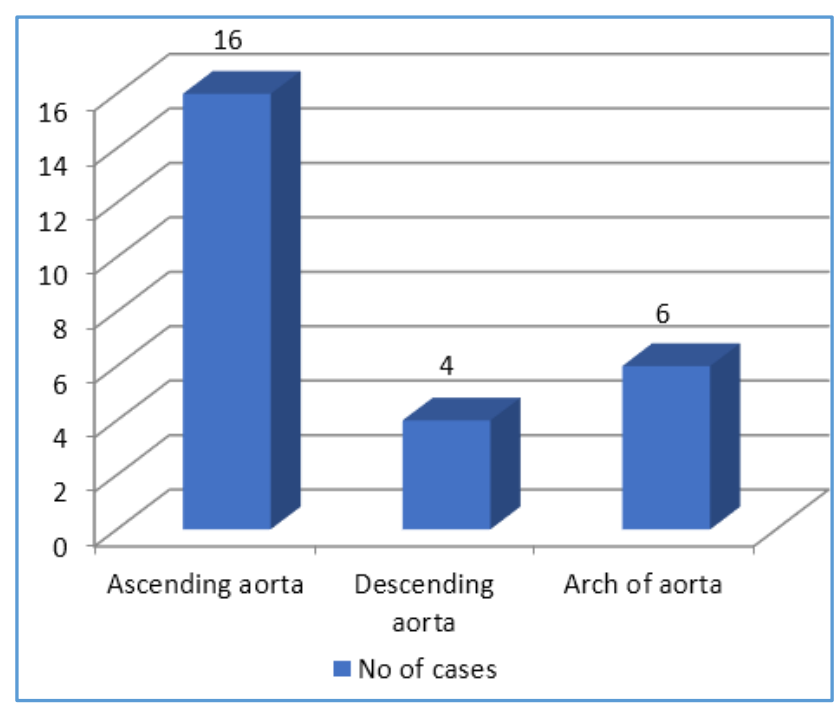

Figure 9. Laceration of Aorta Region Wise

\begin{tabular}{|c|c|c|}
\hline Site of Chest Injury & No. of Cases & Percentage \\
\hline Fracture Ribs (Bilateral) & 88 & 54.6 \\
\hline Fracture Ribs (Unilateral) & 73 & 45.4 \\
\hline Fracture Sternum & 55 & 34.2 \\
\hline Fracture Thoracic Vertebrae & 33 & 20.5 \\
\hline Fracture of Clavicle & 78 & 48.4 \\
\hline Fracture of Scapula & 5 & 3.1 \\
\hline Lung Contusion & 100 & 62.1 \\
\hline Heart Contusion & 34 & 21.1 \\
\hline Laceration of Aorta & 26 & 16.1 \\
\hline Table 9. Distribution of Chest Injuries in Fatal \\
Road Traffic Accidents \\
\hline \multicolumn{3}{|c}{} \\
\hline
\end{tabular}




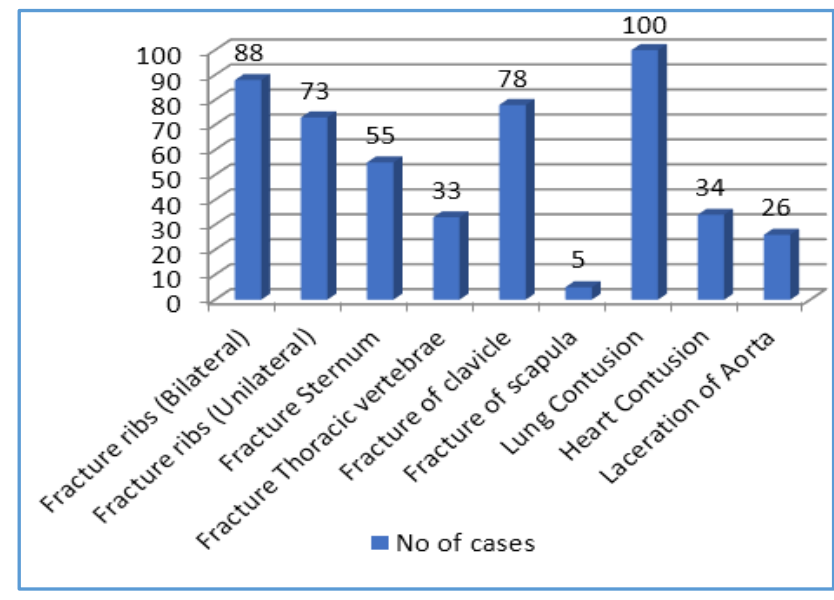

Figure 10. Distribution of Chest Injuries in Road Traffic Accidents

\section{DISCUSSION}

Pedestrians, cyclists and motor cyclists are the most vulnerable road users accounting for around $46 \%$ of global traffic deaths. ${ }^{11}$ The number of total accidents reported in India during the year 2010 was 499,628.12 The total number of accidents reported in Kerala state during the period 2011 was $35,216 .{ }^{13}$ Among these, death occurred in 4145 cases. Road traffic accident deaths are higher in men than in women in all regions regardless of income level and across all age groups. ${ }^{14}$ In India this is partly due to low representation of women in Indian workforce and exposure on roads. 15

Among the 161 cases of fatal road traffic accident victims with chest injuries, 136 (84.5\%) were males and 25 (15.5\%) were females. Maximum number of victims, 57 (35.4\%) were in the age group of $45-60$ years. Maximum number of accidents, 34 (21.1\%) occurred in the month of August and least occurred in the month of October (3.1\%). Maximum number of accidents (41.6\%) occurred during the time $12 \mathrm{PM}$ to $6 \mathrm{PM}$ and least occurrence $(4.3 \%)$ was between $12 \mathrm{AM}$ to 6 AM. Two wheelers were the commonest vehicle involved (53.4\%) followed by car (31.7\%). In case of collisions, cars colliding with two wheelers was the commonest (14.3\%) followed by two wheelers colliding with heavy vehicles $(13 \%)$. Majority of victims involved were pedestrians (38.5\%) followed by motor cyclists (35.4\%). Among the motor cyclists, those wearing helmets were 17 (10.6\%) and those occupants with seat belts were only 2 (1.2\%). Among the drivers $22(13.7 \%)$ were under the influence of alcohol and among the other victims $29.2 \%$ have consumed alcohol. Among the fatal cases $10.6 \%$ died on the spot, $38.5 \%$ died within 6 hours and $41.6 \%$ died within 24 hours. Sternum was fractured in $34.2 \%$, bilateral rib fractures seen in $54.6 \%$ and unilateral fracture in $45.4 \%$. Regarding fracture of thoracic vertebrae, the $4^{\text {th }}$ thoracic vertebra was fractured in 11 $(6.8 \%)$ followed by fracture of $1^{\text {st }}$ and $12^{\text {th }}$ thoracic vertebrae in $4(2.5 \%)$ cases each. Both clavicles were fractured in 6 $(3.7 \%)$. Right lung showed contusion in $58.4 \%$, while left lung was involved in $65.9 \%$. Laceration of right lung was seen in $40.4 \%$, while left lung was involved in $37.9 \%$. Laceration of aorta was seen in $26(16.1 \%)$ cases. Contusion of heart was seen in $34(21.1 \%)$ cases. Laceration of heart was seen in 6
(3.7\%) cases. Associated injury to head was seen in 121 (75.2\%) cases. Of which $25.5 \%$ had intracranial haemorrhages and $49.7 \%$ had fracture of skull. Fracture of cervical spine was seen in 19 (11.8\%) cases, while $44.7 \%$ showed fracture of any of the limbs. Laceration of liver was seen in $54(33.5 \%)$ and spleen was lacerated in $11(6.8 \%)$ of cases.

\section{CONCLUSION}

The mechanism and circumstances of blunt chest injury due to road traffic accidents can be assessed in relation to the number and localisation of rib fractures as well as the presence of injuries to lung, heart and major blood vessels. The most common cause of death $82(50.9 \%)$ was 'combined injuries to head and chest' followed by 'injuries to head, chest and abdomen' $38(23.6 \%)$ and only $6.8 \%$ of cases died due to chest injuries alone.

\section{REFERENCES}

[1] Transport research wing, Ministry of Road Transport and Highways. Road accidents in India 2011. New Delhi: Ministry of Road transport and Highways, Govt. of India, 2012.

[2] United Nations decade of action for Road Safety, 201120. http://www.decadeofaction.org

[3] WHO. Road Traffic Injuries Fact Sheet N0 358, March 2013.

http://who.int/mediacenter/factsheets/fs358/en.

[4] Ministry of Health and Family Welfare. Integrated Disease Surveillance Project-Project Implementation Plan 2004-2009. New Delhi: Govt. of India, 2004:1-18.

[5] Ignatius PC. Forensic Medicine and Toxicology. $1^{\text {st }}$ edn. 2015;9:20.

[6] Krisnan V. Textbook of forensic medicine and toxicology. $6^{\text {th }}$ edn. 2014;19:287.

[7] Sisiopiku VP. Implications of cellular telephony to Traffic safety. 14th ICTCT Workshop, 12, 12, 2010.

[8] Laberge-Nadeau C, Magg U, Bellavance F, et al. Wireless telephones and the risk of road crashes. Accident Analysis and Prevention 2003;35(5):649-60.

[9] Johnson MB, Voas RB, Lacey $\mathrm{JH}$, et al. Living dangerously: driver distraction at high speed. Traffic Injury Prevention 2004;5(1):1-7.

[10] Matthews R, Legg S, Charlton S. The effect of cell phone types on driver's subjective workload during concurrent driving and conversing. Accident Analysis and Prevention 2003;35(4):451-7.

[11] The global burden of disease: 2004 update. Geneva, World Health Organization 2008. http://www.who.int/LinkFiles/reports_GBD_report_2 004 update_fullpdf, 2012

[12] Road accidents in India Annual report. Transport Research Wing of the Ministry of Road Transport and Highways Publishers, 2010.

[13] Road Accident report for the year 2011, State Crime Records Bureau Thiruvananthapuram. http://www.keralapolice.org/newsite/pdfs/gazette/g az_2012/Jan_12/annual_road_\%20accident_reports_ja n12.pdf, 2012. 
[14] Peden M, Scurfield R, Sleet D, et al. The world report on Road Traffic Injury prevention. Geneva, World Health Organization, 2004.
[15] Mohan D. Road accidents in India. Transportation Research and Injury Prevention Programme, Indian Institute of Technology Delhi, New Delhi India. International Association of Traffic and Safety Sciences Research J 2009:33(1):75-9. 